\title{
The Role of Information and Communication Technologies (ICTs) in Delivering Higher Education - A Case of Bangladesh
}

\author{
Shah Md. Safiul Hoque (Corresponding author) \\ School of Business Studies, Southeast University \\ House \# 64, Road \# 18, Block \# B, Banani, Dhaka 1213, Bangladesh \\ Tel: 880-181-758-9168Ｅ-mail: hoque70@gmail.com \\ S. M. Shafiul Alam \\ School of Business Studies, Southeast University \\ House \# 64, Road \# 18, Block \# B, Banani, Dhaka 1213, Bangladesh \\ Tel: 880-172-064-4801Ｅ-mail: shafistore@yahoo.com
}

\begin{abstract}
At present a new era has evolved in the education sector by means of ICTS. Different ICTs are now set to become instrumental to help expand access to education, strengthen the relevance of education to the increasingly digital workplace, and raise educational quality by, among others, helping make teaching and learning into an engaging, active process connected to real life. The application and exposure to and deployment of ICTs fundamentally change the way education is conceived and delivered to students. ICTs are enablers that optimize student-centered pedagogical methods. Due to its easy accessibility this means of education has become very popular all over the world. Distance education has got a thrust after the evolution of ICT-based education system. This paper intends to give an idea about ICT-based higher education all over the globe and its applicability in Bangladesh. Finally, it analyses the responses from different user groups to query about the current status of the ICT-based higher education system Bangladesh.
\end{abstract}

Keywords: ICTs, ICT-based / virtual education, Distance education, Higher education

\section{Introduction}

Education is the backbone of a nation. Despite knowing this, a huge number of people of least developed countries are far beyond the reach of higher education. One of the key reasons may be the poor economic condition of those countries. Perhaps this is the crucial challenge to be addressed by those nations for overall development where education may be on the top list. Information, Knowledge, and Communication Technology also play vital role in the growth as well as producing and offering goods and services at relatively reduced costs. Smart use of ICTs can process information, create knowledgebase and make them available wherever and whenever necessary. But despite having relatively poor economic condition, Information and Communication Technologies (ICTs) in most cases have tremendous success in providing services at reduced costs to the people's door steps. ICTs have the same to do for making the higher education available to all classes of people throughout the country at a lower cost. As a result, on one hand people will have the access right on higher education and on the other hand will gain the necessary knowledge, skills, and experiences to serve the nation and prosper accordingly.

In $21^{\text {st }}$ century, one can hardly find a country where higher education through distance mode is not available. In fact it has been practiced since long before. But at present days, having revolution of ICTs, the higher education through distance mode has been more practical and well accepted by the all people around the globe. It is now being called Virtual learning. In developed country, people are getting more interested in learning through Virtual Campus than that of a Brick-and-Mortar Campus. Virtual Campus is nothing but ICT enabled campus, where students are attending their classes, discussing with teachers, accessing learning resources, seating exams, joining forums/clubs, submitting assignments etc virtually having the facility of real-time interactions between teacher and students. (Figure 1)

\subsection{Definition of terms}

ICTs: ICTs stand for Information and Communication Technologies. According to Blurton, C ICT is defined as "diverse set of technological tools and resources used to communicate, create, disseminate, store, and manage 
information". Technologies included in ICTs are: Redio and Television (broadcasting technology), Telephony, Computers, and the Internet.

WWW: WWW stands for World Wide Web which is one of the most important and widely accepted services (like IRC, E-Mail etc) of the Internet. Its popularity has increased dramatically, simply because it's very easy to use, colorful, and rich in content. "Web is a series of interconnected documents stored on computer sites or websites" (Dennis P Curtin at al (2002)).

E-Learning: Commonly associated with higher education and corporate training, e-learning encompasses learning at all levels, both formal and non-formal, that uses an information network - the Internet, an intranet (LAN) or extranet (WAN) - whether wholly or in part, for course delivery, interaction and/or facilitation. Others also term it as online learning.

E-Payment: Making payment electronically. E-payment is a subset of an e-commerce transaction to include electronic payment for buying and selling goods or services offered through the Internet. Generally we think of electronic payments as referring to online transactions on the internet, there are actually many forms of electronic payments - Credit Card, Digital Check, E-Cash etc. How e-payment does work is depicted in Figure 2.

E-Business: E-Business means interaction with business partners, where interaction is enabled by information technology. E-Business is changing the way we do business. For example, communicating with partners via e-mail, e-brochure, webpage etc.

Group discussion: Internet Relay Chat (IRC) is among the popular Internet service people mostly use for live chatting. Group of people with common interest can exchange views/opinions with each other instantly through Internet. Description of the internet technologies required to support higher education via ICTs (WWW, Video Conference, Tele-Conference, Mobile-Conference, CD, Database, Word processor, Intranet, Internet etc)

E-Modules: Modules written are converted and stored into digital version into a computer using word processor accessible by the user through Internet.

Trust and Security: Existence of six main components of a commerce site suggests trustworthiness as 1) Seals of Approval 2) Brand 3) Navigation (The ease of finding what the visitor seeks) 4) Fulfillment 5) Presentation (Design attributes that suggest quality and professionalism) and 6) Technology. As for security there are also six issues to look into: 1) Integrity, 2) No repudiation (prevention against any one party from reneging on an agreement after the fact), 3) Authenticity (authentication of data source), 4) Confidentiality (protection against unauthorized data disclosure), 5) Privacy (provision of data control and disclosure) and 6) Availability (prevention against data delays or removal)

Teleconferencing: refers to "interactive electronic communication among people located at two or more different places." There are four types of teleconferencing based on the nature and extent of interactivity and the sophistication of the technology: 1) audio conferencing; 2) audio-graphic conferencing, 3) videoconferencing; and 4) Web-based conferencing.

Audio conferencing: involves the live (real-time) exchange of voice messages over a telephone network. When low-bandwidth text and still images such as graphs, diagrams or pictures can also be exchanged along with voice messages, then this type of conferencing is called audio-graphic. Non-moving visuals are added using a computer keyboard or by drawing/writing on a graphics tablet or whiteboard.

Videoconferencing: allows the exchange not just of voice and graphics but also of moving images. Videoconferencing technology does not use telephone lines but either a satellite link or television network (broadcast/cable).

Web-based conferencing: as the name implies, involves the transmission of text, and graphic, audio and visual media via the Internet; it requires the use of a computer with a browser and communication can be both synchronous and asynchronous.

Open and distance learning: Open and distance learning is defined by the Commonwealth of Learning as "a way of providing learning opportunities that is characterized by the separation of teacher and learner in time or place, or both time and place; learning that is certified in some way by an institution or agency; the use of a variety of media, including print and electronic; two-way communications that allow learners and tutors to interact; the possibility of occasional face-to-face meetings; and a specialized division of labour in the production and delivery of courses." (www.col.org/ODLIntro/introODL.htm) 


\section{The objectives of this study are:}

i) To look at ICT-based higher education in other countries

ii) To investigate the current status of ICT-based higher education in Bangladesh

iii) To explore the opinion of academicians and students on ICT-based higher education in Bangladesh

\section{Methodology}

The study is empirical and explorative in nature and therefore the information presented is based on both primary and secondary data. Primary data has been collected using structured questionnaire. In this study stratified random sampling technique was used in terms of respondents. Altogether 150 questionnaires were distributed to and collected from students, teachers, and other professionals equally (50 each). The main aim of the study is to collect opinion from the respondents to examine the state of the role of ICTs in delivering the higher education in the context of Bangladesh. Collected data were duly tabulated and analyzed using spread sheet analysis.

Secondary information has been collected from various documents such as books, newsletters, reports, magazines, journals, daily newspaper, WWW, as well as from existing literature to understand the uses of ICTs for offering various levels of higher education in the western countries.

\section{Literature Review}

ICTs are used as productivity tools or enrichment resources; this generally means that they support the traditional teacher-led mode of instruction in subject areas such as math, language, social studies, or science. Transformative applications of ICTs refer to non-traditional emerging uses where exposure to and deployment of ICTs fundamentally change the way education is conceived and delivered to students. ICTs are enablers that optimize student-centered pedagogical methods. They are used to develop broad, generic skills such as problem solving, independent and collaborative learning, and communication. They lead to more individualized instruction, less didactic delivery, and an emphasis on problem-solving and cooperative learning situations. Teachers assume the role of facilitators and skills developers. They help the students achieve a greater understanding of information by making use of new technologies.

In the past educational institutions have provided little choice for students in terms of the method and manner in which programs have been delivered. Students have typically been forced to accept what has been delivered and institutions have tended to be quite staid and traditional in terms of the delivery of their programs. The use of ICTs provide many options and choices and many institutions are now creating competitive edges for themselves through the choices they are offering students. These choices extend from when students can choose to learn to where they learn. (Oliver, 2002). Another way in which emerging ICTs are contributing significantly on the content of education curricula stems from the ways in which ICTs are dominating so much of contemporary life and work. Already there has emerged a need for educational institutions to ensure that graduates are able to display appropriate levels of information literacy, "the capacity to identify and issue and then to identify, locate and evaluate relevant information in order to engage with it or to solve a problem arising from it" (McCausland, Wache \& Berk, 1999).

The advent of ICTs as learning technologies has coincided with a growing awareness and recognition of alternative theories for learning. The theories of learning that hold the greatest shift today are those based on constructivist principles (eg. Duffy \& Cunningham, 1996). These principles posit that learning is achieved by the active construction of knowledge supported by various perspectives within meaningful contexts. In constructivist theories, social interactions are seen to play a critical role in the processes of learning and cognition. (McCausland, Wache \& Berk, 1999). Contemporary learning theory is based on the notion that learning is an active process of constructing knowledge rather than acquiring knowledge and that instruction is the process by which this knowledge construction is supported rather than a process of knowledge transmission (Duffy \& Cunningham, 1996).

In the publication Victoria L. Tinio (2003) has shown that when used appropriately, different ICTs are said to help expand access to education, strengthen the relevance of education to the increasingly digital workplace, and raise educational quality by, among others, helping make teaching and learning into an engaging, active process connected to real life.

However, investment in ICTs has been controversial. The educational system is fraught with problems and limitations typical of the Third World. Md. Shafiqul Alam (2009) in his paper identified some problems related to ICT-based education: technology and moral issues, affordability, technological imperialism, socialisation and humanisation of technology, appropriateness and acceptability. Opportunities offered by ICT-based education 
may not be beneficial to all learners in countries with different socio-economic, political and cultural environments. The availability of knowledge through technology may cause serious maladjustment to the people of many developing countries. The cost of establishing and maintaining the program economically, culturally, socially or politically must be affordable as globalised system of education. Any replacement or reformation of the use of technology in developing countries needs to be harmonised socially, culturally, economically. Each technology has its own strengths and weaknesses. One medium may serve a teaching function better than another in a particular area, and culture and learners may have different preferences for the technology to best learn with. The socio-economic and cultural background of a person influences their ability to learn from different media technology. Use of new communication technologies requires trained manpower to design, develop, produce and deliver educational material. Few developing countries have adequately trained human resources for these specialised jobs. Among the targeted people they are habituated in a way that providing of education should be done in conventional mode because in some places still people don't have the access to power.

The experience of introducing different ICTs in the classroom and other educational settings for higher education all over the world over the past several decades suggests that the full realization of the potential educational benefits of ICTs is not automatic. The effective integration of ICTs into the educational system is a complex, multifaceted process that involves not just technology indeed, given enough initial capital, getting the technology is the easiest part - but also curriculum and pedagogy, institutional readiness, teacher competencies, and long-term financing, among others.

\section{ICT-based higher education / online education in western countries}

In recent times factors have emerged which have strengthened and encouraged moves to adapt ICTs into class rooms and learning settings. There are a good number of western universities/institutions offering ICT-based higher education successfully with quality for decades. Some of them are (Table 1).

\section{ICT-based education in Asia}

Following the successful use of ICTs in the western countries, current scenario in Asian countries reveals the increased acceptance of ICTs in delivering higher education. (Table 2)

\section{ICT-based higher education or online education in Bangladesh}

Bangladesh, as a least developed country is struggling to make its people educated and well skilled to meet the competition of the global village. As for delivering higher education to the optimum level, both the public and private sectors are working side by side. Bangladesh Open University (BOU) - the only public initiative for offering education through distance mode. The 21 public universities are operating in conventional system in brick-and-mortar campus. There are 54 private universities in the country as well, but among them a few universities offer distance mode education along with class room mode. But none of them are being able to capitalize the blessing of ICTs at optimum level with the view of offering education at all class of people throughout of the country. Bangladesh Open University is the only public institution in the country that imparts education in distance mode. In place of campus based teaching, this university uses technology including electronic devices to reach people in different corners of the country. The learners in this system are not restricted by time, space or age. The main objective of the university is to expand all levels of education in different dimensions in science, agriculture, humanities, and social science etc. and all other that come under the purview of human knowledge and understanding by diversity of means including the use of digital technology. It intends to provide opportunities of education to all classes of people and create efficient and skilled manpower by improving the quality of education.

Bangladesh Open University offers 2 (two) types of programs Formal and Non-formal, through 7 (seven) different schools. BOU already has launched 21 formal and 19 Non -formal programs. Formal programs consist of four levels: Certificate, Diploma, Degree and Masters. Interested people enrolled for the formal programs collect books written specially for them from Regional Resource Centers (RRC), Co-ordinating Offices (CO) and Tutorial Centers (TC). Audio cassettes are also sent out. BOU prepares audio-visual materials and we have been able to arrange for 25 minutes radio broadcast every day and 20-25 minutes television broadcasts five days a week. Each year for every formal program BOU conducts two examination, one each semester. (Table 3)

Southeast University (SEU), a private initiative tried to make its move toward the ICT-based higher education as a pioneer, despite having many challenges on its way forward besides conventional learning systems. ICT-based programs used to be offered by SEU are i) MBA; ii) MA in Islamic Studies and iii) CELP. These programs were conducted via dual mode i.e. ICT-based distance mode and face to face class room mode. 


\section{Findings}

Among the student respondents large percentage is service holders or self employed. This reveals the fact that ICT-based higher education is popular to those who want flexibility in the learning process so that they can do both study and work together (Figure 3). The study reveals that respondents find ICT-based higher education in terms of technical support is quite adequate (Table 4). Where, almost equal number of respondents gave their opinion in favor and disfavor of adequacy of experts (Table 5).

Table 6 indicates that less than 50\% respondent think quality of higher education can be maintained through ICTs means in comparison with face to face conventional learning. Delivery of instruction and its reception by learners, online course materials, for example, may be accessed 24 hours a day, 7 days a week. Table 7 clearly shows that ICT-based education can be offered regardless of time and space (Table 7).

ICTs are a potentially powerful tool for extending educational opportunities, both formal and non-formal. Majority of the respondents agree that ICTs can help access to higher education (Table 8). Slightly less than $30 \%$ of respondents think that ICT-based course materials conform to the needs of the learners, and nearly $30 \%$ think ICT-based course materials fairly adequate. On the other hand, more than $30 \%$ think not adequate (Figure 4 ).

\section{Concluding remarks}

The rigid use of textbook material and its high complexity and great diversity of content does not motivate students, as it imposes great difficulties on them in the understanding of concepts and how to relate the topics being studied with real applications. The findings showed that students prefer the flexibility in the learning process through ICT-based education.

In areas with a continuous change of technological content, as with information and communication technologies, the problem is the difficulty in selecting and organizing the knowledge to be taught. In terms of technical support, experts, and course materials ICT-based education system is expected to enhance its capability to satisfy the user groups. On the one hand, new knowledge has to be added to the curriculum constantly, and at the same time any other knowledge becomes obsolete. On the other hand, content has to be organized and ordered, relating every concept to others, which is not a trivial task because of their number and how often they change.

The ICT-based education system is a holistic approach where a very high level of integrity and moral standard is required by instructors, ICTs experts, students and other stakeholders. To be effective everyone concerned with the process has to upgrade themselves continuously to keep pace with the ever changing environment.

The use of ICTs revolutionized the higher education through virtual campus which has been more practical and well accepted by the all people around the globe. Activities of the virtual Campus are centered around WWW (Figure 1). User groups' understanding and attitude towards WWW are instrumental to the development and sustainability of the system.

Just Copying strategies from advanced world will not serve the purpose of harnessing higher education. While implementing ICT-based education program we have to consider indigenous factors that affect the effectiveness of the operation.

\section{References}

Maria Mercedes T. Rodrigo. (2003). Tradition or transformation? An evaluation of ICTs in Metro Manila schools, Information Technology for Development, IOS Press, p95-122.

Dennis P Curtin at al. Information Technology - The Breaking Wave., Tata McGraw-Hill Publishing Company Ltd 2002, Page- 4.

The Commonwelath of Learning, "An Introduction to Open and Distance Learning"; available from http://www.col.org/ODLIntro/introODL.htm; accessed 14 August 2002.

Oliver, R. (2000). Creating Meaningful Contexts for Learning in Web-based Settings. Proceedings of Open Learning, 2000, (pp 53-62). Brisbane: Learning Network, Queensland.

Duffy, T. \& Cunningham, D. (1996). Constructivism: Implications for the design and delivery of instruction, Handbook of research for educational telecommunications and technology (pp. 170-198). New York: MacMillan.

McCausland, H.,Wache, D. \& Berk, M. (1999). Computer literacy; its implications and outcomes. A case study from the Flexible Learning Centre. University of South Australia.

Victoria L. Tinio. (2003). ICT in Education, http://www.scribd.com/doc/2999093/ICT-in-Education-by-Victoria-L-Tinio, viewed on viewed on 25 June 2009. 
http://www.open.ac.uk viewed on 25 June 2009.

www.epayment.com viewed on 25 June 2009.

http://www.bou.eu.bd/home.html viewed on 25 June 2009.

Blurton, C. (2002). New Directions of ICT-Use in Education. http://www.unesco.org/education/ educprog/lwf/dl/edict.pdf; viewed 7 August.

Alam S. (2009). Technology Based Literacy Education through Distance Mode in Bangladesh: Problems and Prospects, http://www.col.org/pcf2/papers/alam.pdf, accessed on 27 June.

Table 1. ICT-based higher education in western countries

\begin{tabular}{|l|l|l|}
\hline 1 & University of Maryland University & $\begin{array}{l}\text { UMUC offered its first distance education courses in } 1972 . \\
\text { More than } 30 \text { percent of their students are enrolled in courses that do not require on-site } \\
\text { class attendance. The Internet serves as their link to the university. UMUC holds the } \\
\text { highest honor given in Web education }\end{array}$ \\
\hline 2 & Arizona State University, USA & $\begin{array}{l}\text { Expert faculty from highly ranked colleges and schools provide a variety of online } \\
\text { undergraduate programs dedicated to providing the best possible online learning } \\
\text { experience. All online programs carry the same accreditation as our face-to-face programs }\end{array}$ \\
\hline 3 & Open Universities, Australia & $\begin{array}{l}\text { Open Universities Australia is owned by seven leading universities and is the country's } \\
\text { fastest growing online higher education service. Over 110,000 people have studied through } \\
\text { OUA since 1993 with over 900 units and } 60 \text { qualifications from 15 of Australia's best } \\
\text { universities (including Curtin University, Griffith University , Macquarie University, } \\
\text { Monash University, RMIT University etc) and TAFE colleges. One can graduate with a } \\
\text { degree from an Australian university, as if one had studied on-campus. }\end{array}$ \\
\hline 4 & University of Waterloo, Canada & $\begin{array}{l}\text { Through online/distance education one can complete credit courses without attending } \\
\text { on-campus classes. Using well-designed course materials prepared by a Waterloo } \\
\text { instructor, one can study when and where it's most convenient. }\end{array}$ \\
\hline 5 & Open University, England & $\begin{array}{l}\text { The Open University's style of teaching is called 'supported open learning', also known as } \\
\text { 'distance learning'. Some courses include a residential or day school. These are held at } \\
\text { various times and locations. The course materials may use any of the following different } \\
\text { media that may be used from home: printed course materials, set books, audio cassettes, } \\
\text { video cassettes, TV programmes, cd-Rom/software, web site, home experiment kit, } \\
\text { teleconferencing. }\end{array}$ \\
\hline
\end{tabular}


Table 2. ICT-based education in Asia

\begin{tabular}{|c|c|c|}
\hline 1. & Malaysia & $\begin{array}{l}\text { Higher education institutions using teleconferencing in their online learning programs include the Unitar } \\
\text { (Universiti Tun Abdul Ruzak) in Malaysia, Open University of Hong Kong, and Indira Gandhi National Open } \\
\text { University. }\end{array}$ \\
\hline 2. & South Korea & $\begin{array}{l}\text { South Korea has one of the most advanced ICT infrastructures in the world. The pervasiveness of ICT use in } \\
\text { South Korean society has spilled over to the higher educational system. South Korea currently has } 15 \\
\text { single-mode virtual universities that offer only ICT-based courses. Among these are the Korea Cyber University, } \\
\text { the Korea Digital University, and the Open Cyber University. These universities specialize in lifelong learning } \\
\text { and vocational education-a deliberate strategy to prevent unnecessary competition with more established } \\
\text { campus-based universities-and have a combined projected enrolment of } 17,200 \text { in } 2002 \text {. Courses offered cover } \\
\text { a wide range of fields, including technology, management, law, languages, social sciences, education, and } \\
\text { theology. }\end{array}$ \\
\hline 3 & Indonesia & $\begin{array}{l}\text { Since its establishment in } 1984 \text { as the first distance and open learning institution in Indonesia, the Universitas } \\
\text { Terbuka (Indonesian Open Learning University) has made great strides in making higher education available to } \\
\text { Indonesians, having served more than } 400,000 \text { students nationwide in its } 14 \text { years of existence. The mandate of } \\
\text { Universitas Terbuka, however, is not only to expand educational opportunity but also to "improve the quality of } \\
\text { education and make it more relevant to national development needs." } 18 \text { In its effort to address issues of quality } \\
\text { in instruction, it has recently introduced the use of the Internet and a combination of facsimile and Internet } \\
\text { technologies for student tutorials in } 40 \text { of its more than } 700 \text { courses on offer. These electronic tutorials are a } \\
\text { supplement to more traditional tutorial models - including face-to-face, regular mail, radio and television - } \\
\text { already employed by the university. }\end{array}$ \\
\hline 4. & Philippines & $\begin{array}{l}\text { At the University of the Philippines Open University (UPOU), course materials are still predominantly print } \\
\text { based but online tutorials are becoming a convenient alternative to face-to-face tutorials especially for students } \\
\text { unwilling or unable to go to UPOU's various physical learning centres. About } 70-90 \% \text { of UPOU's degree } \\
\text { courses offer online tutorials as an option, while in several of its non-degree courses tutorials are conducted only } \\
\text { online. }\end{array}$ \\
\hline
\end{tabular}

Table 3. Programs of BOU

\begin{tabular}{|c|c|c|c|}
\hline \multicolumn{4}{|c|}{ Program wise total students enrolment in 2008} \\
\hline SL\# & Schools & Name of the Program & Total Enrollment \\
\hline 01 & \multirow{3}{*}{ School of Education } & M. Ed & 2,525 \\
\hline 02 & & B. Ed & 3,563 \\
\hline 03 & & C. Ed & 1423 \\
\hline 04 & \multirow{3}{*}{ Open School } & SSC & $1,20,138$ \\
\hline 05 & & HSC & 72,678 \\
\hline 06 & & BBS & 791 \\
\hline 07 & \multirow{4}{*}{ School of Social Science Huminities and Languages } & BA/BSS & 64,462 \\
\hline 08 & & CELP & 275 \\
\hline 09 & & CALP & 122 \\
\hline 10 & & BELT & 68 \\
\hline 11 & \multirow{4}{*}{ School of Agriculture and Rural Development } & B.Ag.Ed & 1,317 \\
\hline 12 & & CPFP & 60 \\
\hline 13 & & CLP & 168 \\
\hline 14 & & DYDW & 17 \\
\hline 15 & \multirow{4}{*}{ School of Business } & PGDM/CIM & 189 \\
\hline 16 & & BBA & 1209 \\
\hline 17 & & MBA & 529 \\
\hline 18 & & CEMBA/CEMPA & 174 \\
\hline 19 & \multirow{2}{*}{ School of Science and Technology } & DCSA & 529 \\
\hline 20 & & B. Sc in Nursing & 1,393 \\
\hline \multicolumn{3}{|c|}{ Total Students enrolment up to October 2008} & $2,71,630$ \\
\hline
\end{tabular}

(Source: http://www.bou.eu.bd/home.html) 
Table 4. Technical support

\begin{tabular}{|l|l|l|l|}
\hline \multirow{2}{*}{ Respondents } & \multicolumn{2}{|l|}{ Is there satisfactory technical support for offering ICT-based higher education? } \\
\cline { 2 - 4 } & Yes (\%) & No (\%) & Indifferent (\%) \\
\hline Students & 55 & 30 & 15 \\
\hline Teachers & 47 & 44 & 9 \\
\hline Other & 53 & 31 & 16 \\
\hline
\end{tabular}

Table 5. Adequacy of experts

\begin{tabular}{|c|c|c|c|}
\hline \multirow[t]{2}{*}{ Respondents } & \multicolumn{3}{|c|}{$\begin{array}{l}\text { Do you think that there are adequate experts for implementing ICT-based higher } \\
\text { education? }\end{array}$} \\
\hline & Yes (\%) & No (\%) & Indifferent (\%) \\
\hline Students & 48 & 40 & 12 \\
\hline Teachers & 42 & 45 & 15 \\
\hline Other & 43 & 47 & 10 \\
\hline
\end{tabular}

Table 6. Quality of ICT-based higher education

\begin{tabular}{|c|c|c|c|}
\hline \multirow[t]{2}{*}{ Respondents } & \multicolumn{3}{|c|}{$\begin{array}{l}\text { Do you think that quality of higher education can be ensured as like as face-to-face } \\
\text { conventional education system? }\end{array}$} \\
\hline & Yes $(\%)$ & No (\%) & Indifferent (\%) \\
\hline Students & 52 & 38 & 10 \\
\hline Teachers & 40 & 48 & 12 \\
\hline Other & 45 & 46 & 9 \\
\hline
\end{tabular}

Table 7. Transcendence of time and space

\begin{tabular}{|l|l|l|l|}
\hline \multirow{2}{*}{ Respondents } & \multicolumn{3}{|l|}{ Does ICT-based education have the ability to transcend time and space? } \\
\cline { 2 - 4 } & Yes (\%) & No (\%) & Indifferent (\%) \\
\hline Students & 77 & 15 & 8 \\
\hline Teachers & 71 & 14 & 15 \\
\hline Other & 75 & 16 & 9 \\
\hline
\end{tabular}

Table 8. Access to higher education

\begin{tabular}{|l|l|l|l|}
\hline \multirow{2}{*}{ Respondents } & \multicolumn{2}{|l|}{ Can ICTs help expand access to education? } & Indifferent (\%) \\
\cline { 2 - 4 } & Yes (\%) & No (\%) & 10 \\
\hline Students & 69 & 21 & 13 \\
\hline Teachers & 63 & 24 & 18 \\
\hline Other & 59 & 23 & \\
\hline
\end{tabular}




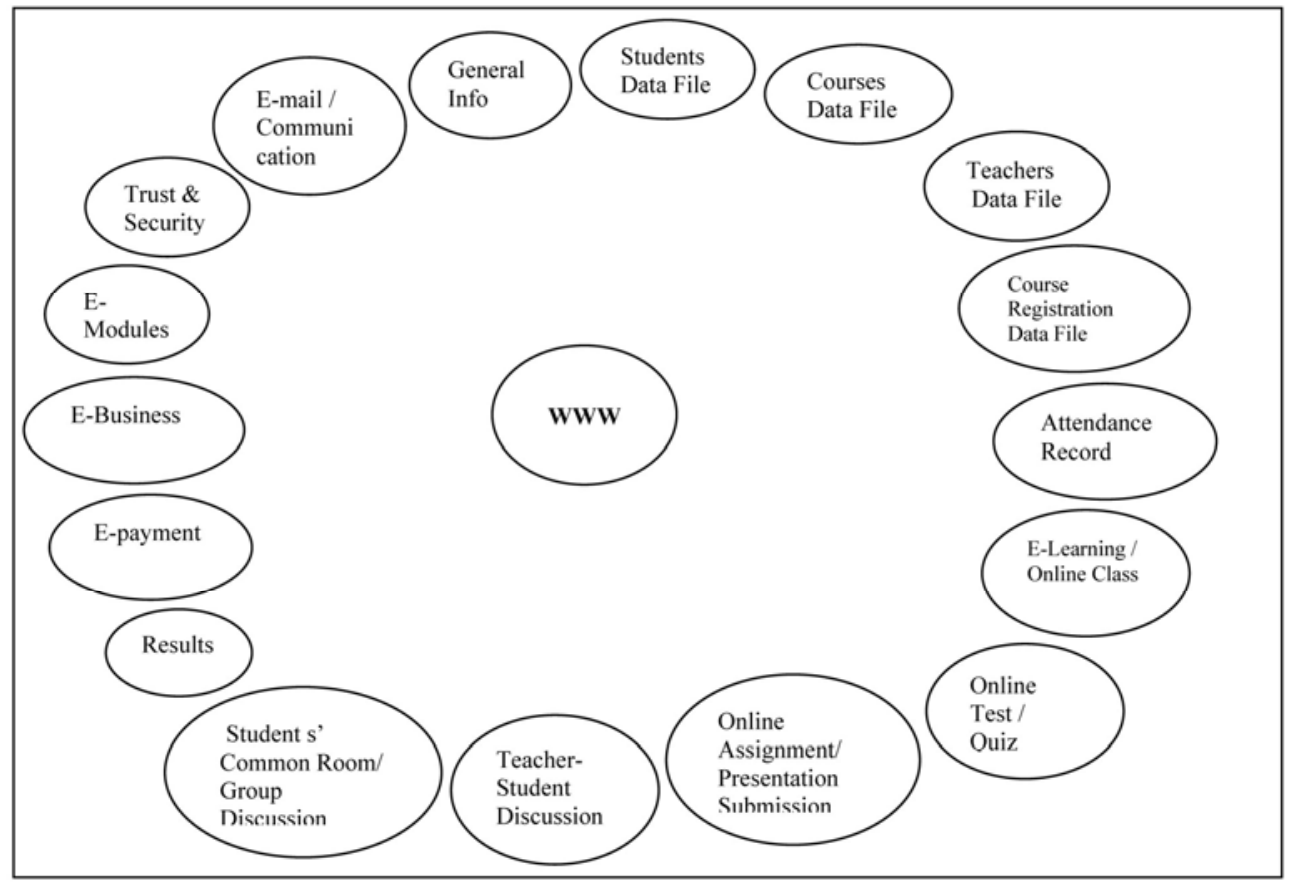

Figure 1. Services and Interactions through WWW for ICT-based / Virtual Education

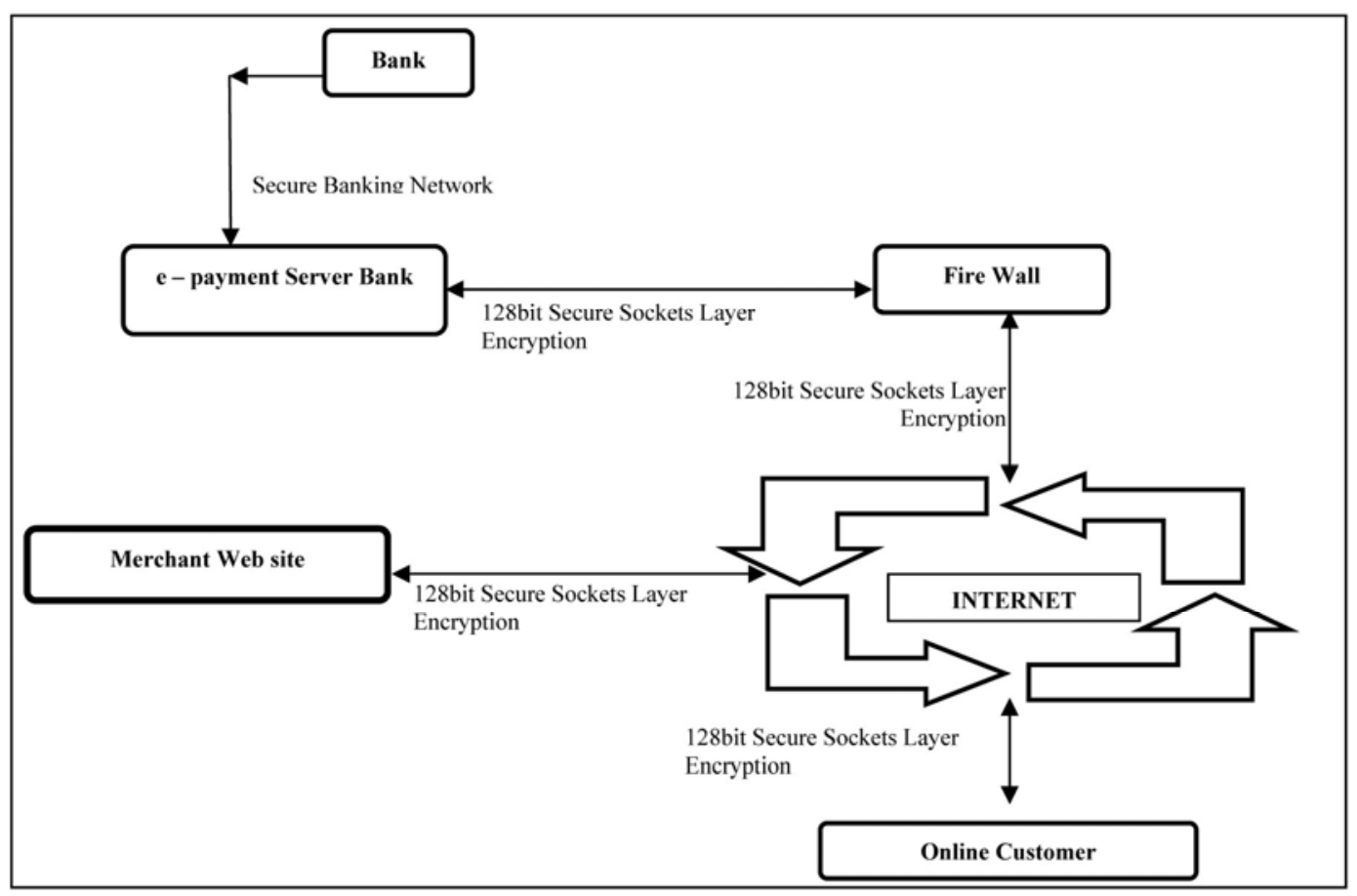

Figure 2. E-Payment process (Source: www.epayment.com) 


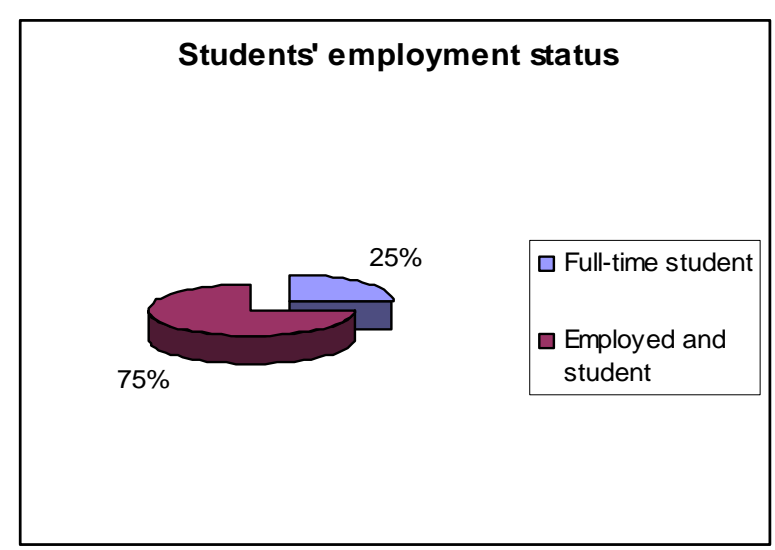

Figure 3. Students' employment status

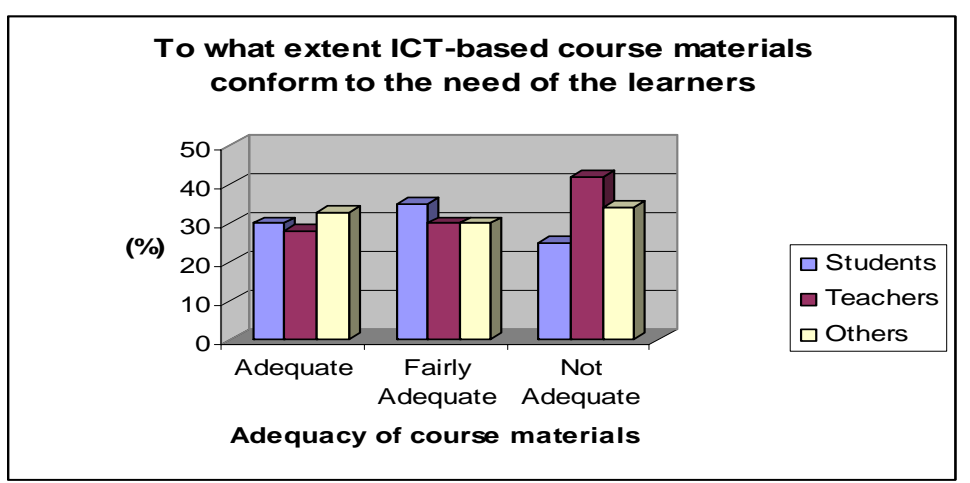

Figure 4. Meeting the needs of the learners 